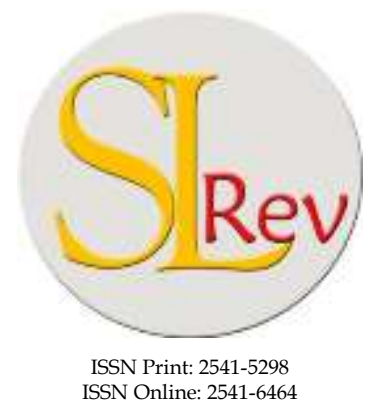

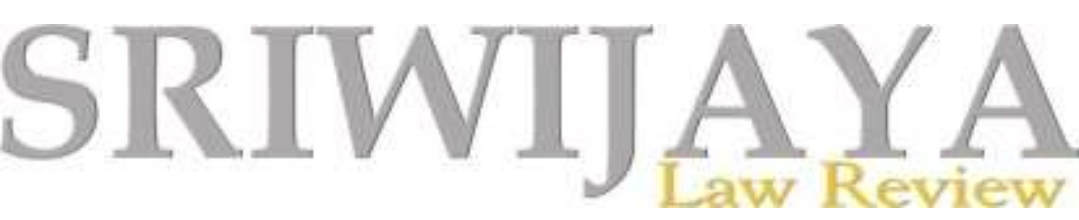

Editorial Office: Faculty of Law, Sriwijaya University, Jalan Srijaya Negara, Palembang, South Sumatra 30139, Indonesia. Phone: +62711-580063Fax: +62711-581179

E-mail: sriwijayalawreview@unsri.ac.id|sriwijayalawreview@gmail.com

Website: http://journal.fh.unsri.ac.id/index.php/sriwijayalawreview

\title{
The Admissibility of Scientific Expert Evidence Under Indonesian Criminal Justice System
}

\author{
Wanodyo Sulistyani*
}

\begin{abstract}
In many cases, such as corruption and forestry-related crimes, an expert has a significant role in explaining the impact of the crime. For instance, scientific expert evidence is required to disclose about the ecological destruction that occurred due to the defendant's criminal activities. In practices, the issue with scientific expert evidence is supposed to be about its admissibility in court. For this issue, the U.S. Court applies Rules of Evidence in considering the admissibility of scientific expert evidence at trial. Those are some requirements (prong test) to be met before expert testimony is admissible. In contrast, the Indonesian Criminal Procedural Law (KUHAP) or other laws do not set any prong test for presenting specialist scientific evidence to be acceptable. Lack of such proof may impact criminal justice process reliability and place expert under vulnerable position. Therefore, this paper will explore the issue on scientific expert evidence under Indonesian criminal law as well as its consequences and impacts for the Indonesian criminal justice process.
\end{abstract}

Keywords: Criminal Justice System; Indonesia; Lawsuit; Scientific Expert Evidence.

\section{ARTICLE HISTORY:}

\section{DOI: 10.28946/sIrev.Vol3.Iss2.215.pp152-161}

Received: Nov 18, 2018;

Reviewed: Jul 8, 2019;

Accepted: Jul 27, 2019;

Published: Jul 31, 2019.

Faculty of Law, Universitas Padjadjaran, Indonesia.E-mail: wanodyo@unpad.ac.id

\section{INTRODUCTION}

In usual practices, admissibility of evidence becomes an issue, including in the criminal justice process. One of the problems is regarded to the admissibility of scientific expert evidence in court, for instance, is in the United States Court. Referring to the criminal case of Frye $v$. the United States in 1923, the so-called Frye test was enunciated by the Court of Appeals of the District of Columbia regarding the standard for scientific expert evidence to be admissible at trial. In many cases, the Frye test was applied, and it spread quickly. Considering the fact, the Frye test was then promulgated in the Federal Rules of Evidence in 1975. Nevertheless, in 1993, the Frye test was challenged in the civil case of Daubert $v$. Merrel Dow Pharmaceuticals. In this case, the U.S. Supreme Court finally rejected the Frye test. Since that, the practice regarding the admissibility of scientific expert evidence has changed. ${ }^{1}$

\footnotetext{
Under Daubert, testability, error rate, the existence of standards, peer review, and general acceptance are some assessments for judges to examine the reliability of scientific expert evidence. See. Gross, Samuel R. and Mnookin, Jennifer L, 2003, "Expert Information and Expert Evidence: A Preliminary Taxonomy," Seton Hall Law Review Vol. 34:141, p142.
} 
From both cases, the scientific theory, method, and technique determine either the evidence was admissible or excluded at trial. Once the expert failed to demonstrate that the theory, method, or technique was acceptable and reliable, the expert's testimony will be abandoned at trial. Those cases also indicate that scientific expert evidence was open to being challenged.

Nevertheless, rather than challenging the expert testimony at trial, the perpetrator in criminal cases prefers to file a lawsuit against the expert. The perpetrator's action may tamper the experts in giving their evidence. This practice also may cause other experts reluctant to assist, particularly in helping the prosecutor or government, in the criminal justice process.

Recently, Indonesia judges considered scientific expert evidence in the bribery case of Nur Alam, former Southeast Sulawesi governor and forest fires case of P.T. Jatim Jaya Perkasa (JJP) to be relevant in their verdict. As consequences of their testimony in those criminal cases, Basuki Wasis and Bambang Hero Saharjo have to deal with a civil lawsuit against them. The party in the civil suit against Basuki Wasis was Nur Alam; while JJP became a party that filed a lawsuit against Bambang Hero Saharjo.

Initially, Basuki Wasis gave his testimony in the bribery case of Nur Alam. In his testimony, Basuki Wasis explained about scientific evidence that indicates ecological destruction regarding mining activities of P.T. Anugerah Harisma Barakah (AHB) in Kabaena Island, Southeast Sulawesi. Nur Alam has allegedly accepted bribery from AHB while issued the mining license to AHB. Therefore, Nur Alam was also liable for restitution to restore the ecological destruction at Kabaena Island. Disagree with Basuki Wasis' testimony, Nur Alam claimed losses and filed a civil lawsuit against Basuki Wasis. In his lawsuit, Nur Alam sued Basuki Wasis for material and immaterial losses in the amount of Rp. 1.7 billion and Rp. 3 trillion. $^{2}$

Similar to Basuki Wasis, a civil lawsuit against Bambang Hero Saharjo was filed by P.T. Jatim Jaya Perkasa (JJP) due to his testimony against the company in forest fires case. According to Bambang Hero Saharjo, the burning that started by the company covered about 1000 hectares of peatland. ${ }^{3}$ In this case, Vitoni Immanuel Siboro, the executive of JJP was found guilty, and the court sentenced him for four-year imprisonment and an Rp. 3 billion fine. ${ }^{4}$ Previously, JJP was also imposed an Rp. 1 billion fine by the Rokan Hilir District Court. Claimed losses, JJP was then sued Bambang Hero Saharjo for unlawful deed under the civil lawsuit. Although JJP has revoked its claim, yet this practice will deteriorate the expert involvement to assist the prosecutor or government in the criminal trial.

Understandably that expert is giving his/her testimony based on his/her expertise. To testify as an expert, he/she should be qualified by knowledge, skill, experience, or education. Failed to meet those qualifications, he/she cannot consider

2 Lusia Arumingtyas, (2018) Kala Kuasa Hukum Nur Alam Perkarakan Saksi Ahli Lingkungan, Berikut Pandangan Koalisi. Available from: http://www.mongabay.co.id/2018/04/21/kalakuasa-hukum-nur-alam-perkarakan-saksi-ahlilingkungan-berikut-pandangan-koalisi/, [retrieved: September 31, 2018)].

3 The Pekanbaru High Court verdict number 186/PID.SUS/2015/PT.PBR. p36.

$4 \quad$ Note 3. p44. 
as an expert. Under the Indonesian criminal law procedure, the judge may consider the expert testimony in their verdict. It means that there is no obligation for the judge to examine it under their verdict. The defendant may provide other expert testimony to challenge the evidence for his/her favor.

A civil lawsuit against the expert indicates that expert is susceptible to be tampered, as consequences of his/her testimony, especially in white-collar crime cases such as corruption and forestryrelated crimes. This practice also becomes justification that the expert testimony is material for a civil lawsuit; while understandable that the expert testimony is a material to be challenged in the evidentiary process. Compare to the U.S, Indonesian criminal law procedure does not regulate such evidentiary rules where some requirements should be met before expert testimony is admissible at trial. Lack of such regulations may impact the reliability of the Indonesian criminal justice process and place expert in a vulnerable position. Therefore this article will explore the issue on scientific expert evidence under criminal law procedure also its consequences and impacts for the criminal justice process.

\section{ANALYSIS AND DISCUSSION \\ White-Collar Crime Under the Perspective of Law Enforcement}

Initially, the term "white-collar crime" was coined by Edwin Sutherland, a criminologist. This term refers to harmful business activities, which difficult to be prosecuted. Thus, many studies endeavor to define those hazardous business activities as crimes and consider to be socially controlled. ${ }^{5}$

On the early stage of the approach, Sutherland emphasized his study on whitecollar crime to the social status of the perpetrator, such as a member of a political party or economic elite, rather than the characteristic of white-collar crime. Subsequently, the U.S. Justice Department develops the study of white-collar crime and refers not narrowly to the perpetrator as mentioned by Sutherland-, but more to "those classes of nonviolent, illegal activities which principally involve traditional notions of deceit, deception, concealment, manipulation, breach of trust, subterfuge or illegal circumvention." ${ }^{6}$ The U.S. Justice Department indicates that white-collar crime includes more than about the perpetrator, yet also about the illegal activities as mentioned above.

In many cases of white-collar crime, such as corruption, criminal law officer have to deal with many obstacles. The highrank position of the perpetrator may cause difficulties in detecting illegal activities. Also, criminal law officer has to struggle with collected evidence since victims are undetected, lack of resources, and the perpetrator has many resources to evade the prosecution. Those situations have reduced the opportunity to punish the perpetrator. ${ }^{7}$

Besides, from the perspective of the prosecutor, white-collar crime is distinguished from street crime. Some

5 Schlegel, Kip et al., 2000-2001. “Are WhiteCollar Crimes Overcriminalized? Some Evidence on the Use of Criminal Sanctions Against Securities Violators," 28 W. St. U. L. Rev. 117, p117.

6 Proveda, Tony G, 1994, "Rethinking WhiteCollar Crime," Wisconsin Lawyer, p59.

7 Proveda, Tony G. Note 6. 
indicators to distinguish white-collar crime from street crime are as followed: ${ }^{8}$

1. The victims of white-collar crime do not recognize that they have been victimized. The position of trust of the putative defendant has caused the victims less suspicious of the irregular activities of the defendant. Thus, the victims do not recognize their victimization.

2. Compare to the investigation of a street crime; white-collar crime investigation is more complicated. The length of time for the occurrence of white-collar crime caused difficulties to collect evidence since it involved many complicated transactions, documents, and perpetrators. Managing proof becomes more difficult since the victims do not recognize that they have been victimized. These difficulties impact the effectiveness of a white-collar crime investigation.

3. White-collar crime has a stringent correlation with civil law. White-collar crime is potentially to proceed through administration, public, or criminal law procedure; for instance, is forestryrelated crimes.

\section{The Admissibility of Scientific Expert Evidence at Trial}

Article 1 Para. 28 of the Law No. 8 of 1981 concerning [Indonesian] Criminal Procedural Law (KUHAP) stipulates that expert testimony is testimony-based expertise for the interest of evidentiary in the criminal justice process. Distinguished from witness testimony, an expert should

8 Bucy, Pamela H, 1989, "White Collar Crime and the Role of Defense Counsel," 50 Ala. Law. 226, pp226-228. have knowledge or competency in a related field of expertise which essential to prove the case; while witness testimony is based on what he/she saw, heard, or experienced about the crime and its expansion according to Constitutional Court verdict number 65/PUU-VIII/2010.9

Furthermore, to understand about expert, KUHAP and Circular Letter of the Supreme Court of the Republic of Indonesia (Surat Edaran Mahkamah Agung Republik Indonesia/SEMA RI) stipulated about expert categorization. Those categorizations are as followed:

1. Article 132 paragraph (1) KUHAP refers to Graphologist;

2. Article 133 paragraph (1) KUHAP and Article 179 paragraph (1) KUHAP refer to forensic expert;

3. SEMA RI Number 13 of 2008 about Requesting Expert Testimony refers to the Press Board as an expert for pressrelated crimes;

However, KUHAP does not give any further explanation about the admissibility of expert testimony at trial, including nonscientific or scientific expert evidence. Without any prong test to determine whether expert testimony is admissible or excluded at trial, the reliability of expert may be questioned. For instance, was in a case which involved Roy Suryo, who was reported by the Information and Telecommunication (IT) Academics forum to the police for his claimed as IT expert. Roy Suryo's expertise was questioned since

9 Constitutional Court Judges expanded the definition of the witness by not limited to who saw, heard or experienced the crime; but also who can testify in investigating, prosecute, and for the interest of trial without he/she saw, heard, or saw the crime. Constitutional Court Verdict Number 65/PUU-VIII/2010, p92. 
his education background is not an IT field of knowledge. ${ }^{10}$

In contrast, related to scientific expert evidence, the U.S. Court set prong test to determine whether the scientific expert evidence is admissible or excluded at trial. Initially, through the criminal case of Frye v. the United States in 1923, the U.S. Court set -what so-called Frye-test for scientific expert evidence to be admissible at trial. Under the Frye test or also known as the general acceptance test, some requirements should be met to determine the admissibility of scientific expert evidence. In this case, the Court of Appeals of the District of Columbia enunciated the expert testimony to be admissible when it is "sufficiently established to have gained general acceptance in the particular field in which it belongs." 11 The Court, in this case, concluded that the expert failed to demonstrate general acceptance among physiological and psychological authorities regarding systolic blood pressure deception test. $^{12}$

However, in 1993, the Frye test was challenged by other courts. In the civil case of Daubert v. Merrel Dow

10 Liberty Jemadu, (2013) Forum Akademisi IT Pertanyakan Predikat "Ahli Telematika" Roy Suryo. Available from: http://www.beritasatu. com/kesra/134829-forum-akademisi-itpertanyakan-predikat-ahli-telematika-roysuryo.html, [retrieved: September 31, 2018].

11 Deaton, Dana G, 1996, "The Daubert Challenge to the Admissibility of Scientific Evidence," 60 Am. Jur. Trials 1, p5.

12 Deaton, Dana G. Note 11, In Frye v. the United States, the defendant offered scientific expert evidence which then excluded by the Court because it did not meet the requirement of general acceptance. The Court of Appeals affirmed the judgment that the defendant was convicted of murder in the second degree. The Frye test spread quickly, and then it promulgated under the Federal Rules of Evidence in 1975.
Pharmaceuticals, ${ }^{13}$ The Court rejected the "general acceptance" in the Frye test. The Court, in this case, enunciated the admissibility of scientific expert evidence must be met some requirements as followed:

1. To determine the expert testimony as scientific expert evidence, the testimony must constitute "scientific knowledge"; ${ }^{14}$ As gatekeeping, judges should determine about "scientific" and "knowledge." In this matter, Court concluded that "scientific" refers to the ground of methods and procedures of science; while "knowledge" refers to more than subjective belief or unsupported speculation. ${ }^{15}$

2. To advancing a material of the case, the proposed expert testimony must be "fits." 16 Fits mean that the applied theory must be fit with the case. In this matter, the Court has to determine whether the expert testimony fits with the facts of the case or not. ${ }^{17}$

In practice, the Daubert test also applies for criminal cases to determine whether the scientific expert evidence is admissible or excluded at trial. For

13 Deaton, Dana G. Note 11. In this case, a civil lawsuit was filed against Merrel Dow Pharmaceuticals by two minors and their parents. To alleviate morning sickness, the minors mothers took Bendectin during their pregnancies, which then caused the minors' congenital disability.

14 Deaton, Dana G. Note 11, p6.

15 Berger, Margaret A, 1994, "Procedural Paradigms for Applying the Daubert Test," 78 Minn. L. Rev. 1345, p1350.

16 Deaton, Dana G. Note 11, p6.

17 Berger, Margaret A. Note 15, p1351. 
instance, forensic techniques are generally allowable in criminal cases. ${ }^{18}$

\section{Consequences and Impacts of Scientific Expert Evidence For Criminal Justice Process}

Evidentiary becomes an essential process in the criminal trial. Through evidentiary, the presented evidence will be assessed to determine the defendant's criminal liability. If the defendant is liable, then the Court will assert the punishment.

Indonesia has regulated expert testimony examination under criminal law procedure. ${ }^{19}$ Initially, judges at trial have a significant role in exploring the presented specialist testimony. According to Article 180 KUHAP, if it is necessary, the judges may request expert testimony at trial and new material to the interested parties. ${ }^{20}$ Furthermore, the judge may also request recurrent research if the defendant or his/her lawyer is objected. ${ }^{21}$

To ensure that the expert testimony is reliable, the defendant also has the right to present other expert testimony for his/her favor. $^{22}$ The defendant's presented expert testimony is to challenge the prosecutor's evidence. Although the burden of proof is in the Prosecutor, KUHAP provides an opportunity for the defendant to defend his/herself from incrimination.

In correlation with scientific expert evidence, in giving testimony, the expert should describe scientific theories,

18 Goodwin, Robert J., 2012. "An Overview of Alabama's New Daubert-Based Admissibility Standard," 73 Ala. Law. 196, p199.

19 Rifai, E, 2017, "An Analysis of the Death Penalty in Indonesia Criminal Law," Sriwijaya Law Review, 1(1), pp191-200.

20 Article 180 paragraph (1) of KUHAP.

21 Article 180 paragraph (2) of KUHAP.

22 Article 65 of KUHAP. methods, or techniques that he/she applies to explain its relationship with the fact of the case sufficiently. This practice has been admitted under the U.S law. Under Federal Rules of Evidence ${ }^{23}$, the U.S Court set a test for scientific expert evidence ${ }^{24}$ to be admissible. Unfortunately, Indonesia does not set such test yet.

Although Indonesian criminal law procedure does not set prong test to determine whether scientific expert evidence is admissible or excluded at trial; the Court still able to examine the evidence, since the judge has an active role in questioning the fact and presented evidence. Besides, prosecutor and lawyer also have a significant role in exploring facts and evidence at trial. Lack of prong test will raise an issue if presented scientific expert evidence is contradictory one to another. This situation may occur at criminal case trial, though experts examine the same scientific evidence; yet, the various scientific methodology may be applied to explain the evidence. It, of course, generates different results. Since judge, prosecutor, and lawyer are non-scientific

23 Rule of evidence is not about one party presented evidence at court for his/her favor; yet, it prevents parties from presenting evidence which other party is objected, or even the Court is rejected. See. Richard Glover, Murphy on Evidence, Oxford University Press, p1.

${ }^{24}$. In dealing with scientific evidence, the Court must treat it very thorough. It means that the Court should ensure the presented scientific evidence based on valid and reliable scientific methodology. In this matter, judges may apply established criteria of related science communities. Besides, scientific evidence also acknowledges under the community as valid and reliable. See. William Daubert, et al., Petitioners v. Merrel Dow Pharmaceuticals, Inc., Respondent, on Writ of Certiorari to the United States Court of Appeals for the Ninth Circuit, 1993 WL 13006281 (U.S.) (Appellate Brief) United States Supreme Court Amicus Brief, p3. 
fact finder, these differences become an obstacle in seeking the truth.

The expert role is vital since scientific evidence is challenging to be understood by non-scientific fact-finders. ${ }^{25}$ Expert testimony assists the judge to find nexus between scientific evidence and the case's facts. Without expert assistance, the judge will not be able to deliver about scientific evidence in their verdict's consideration and to prove the defendant's guilt beyond a reasonable doubt.

Concerning white-collar crime, scientific expert evidence is essential since the impact of white-collar crime requires expert assessment. For instance, in forestryrelated crime, to assess the ecological destruction caused by forest fires, the expertise of an expert in a related field of knowledge is required. This evidence will also determine the defendant liability in causing harmful effects of such crimes.

Some criminal cases, such as corruption and forestry related crimes, have presented scientific expert evidence in court. In the bribery case of Nur Alam, former Southeast Sulawesi governor, scientific evidence was presented. In that trial, Basuki Wasis as an environmental expert and lecturer at Faculty of Forestry explained about the scientific evidence that indicated ecological destruction. As the prosecutor presented expert, Basuki Wasis calculated restitution to restore the environmental damage caused by mining activities of AHB. Nur Alam was assumed liable since he was as the governor of

25 William Daubert, et al., Petitioners v. Merrel Dow Pharmaceuticals, Inc., Respondent, On Writ of Certiorari to the United States Court of Appeals for the Ninth Circuit, 1993 WL 13006281 (U.S.) (Appellate Brief) United States Supreme Court Amicus Brief, p5.
Southeast Sulawesi issued mining license to AHB. Nur Alam rejected Basuki Wasis' testimony. Rather than challenged it at trial, Nur Alam prefers to file a civil lawsuit against Budi Wasis.

Similar to Basuki Wasis, Bambang Hero Saharjo gave testimony of forest fires of JJP. Using his expertise, Bambang Hero explained about the burning of 1000 hectares of peatland which initiated by JJP. For his statement, Bambang Hero Saharjo had been sued by JJP for unlawful deed.

Both cases indicate that the lack of prong test on the admissibility of scientific expert evidence has placed expert in a vulnerable position. Logically, expert testimony as evidence is open to be challenged at trial, and he/she is not subject for a lawsuit, since his/her testimony based on scientific methodology. The lawsuit against experts for his testimony may hamper them in giving evidence; furthermore, these actions will deteriorate other experts in assisting prosecutor or government in revealing criminal cases. ${ }^{26}$ Although Indonesia has regulated some rules to protect expert from intimidation, violence, and other forms of violence, ${ }^{27}$

26 Helena Primadianti, \& Zuhro, F. (2018). A Gap Between Right to Live Protection and Death Penalty in Indonesia (Judges Decision on Cases Threatened Death Penalty). In SHS Web of Conferences (Vol. 54, p. 02005). EDP Sciences.

27 Under Article 28 paragraph (3) The 2014 Law No. 31 Concerning Witness and Victims Protection, expert will be served for protection based on the importance of his/her testimony and threat level which may jeopardize the expert security. The protection is enumerated under Article 5 paragraph (1), excluded about the immunity of expert from being sued or prosecuted concerning his/her testimony. 
Still, those rules do not prevent the expert from being sued by the defendant. ${ }^{28}$

Scientific expert evidence is understandable to be accounted for its validity and reliability. An explanation about scientific evidence requires scientific theories, methods, and techniques that are valid and reliable. If another party is objected with the evidence, he/she may challenge by presenting other scientific expert evidence. As a gatekeeping, the judge has a significant role in understanding and putting his/her belief under presented scientific expert evidence of both parties.

Even without any regulation about prong test to consider the admissibility of scientific expert evidence at trial, the judge may assess the expert testimony by questioning more about the methodology and the procedure of science that he/she applied. Also, the judge should consider very thorough whether the expert testimony fits with the facts of the case or not.

Also, expert testimony has dual characters in correlation with its forms. First, specialist testimony is as a report, ${ }^{29}$

28 MaPPI FHUI, (2018) Diskusi Indonesian Center for Environment Law (ICEL) "Anti SLAPP dan Perlindungan Terhadap Kriminalisasi Aktivis. Available from: http://mappifhui.org/2018/ 02/13/diskusi-indonesian-center-environmentlaw-icel-anti-slapp-dan-perlindungan-terhadapkriminaliasi-aktivis/, [retrieved: October 30, 2018]. Under Article 66 of Law Number 32 of 2009 about the Environment Protection and Management jo. Supreme Court Decree Number 36/KMA/5K/II/3013 about the Implementation of Guidelines for Handling Environment Cases, Anti Strategic Lawsuit Against Public Participation concept (Anti SLAPP) was acknowledged. This concept is to protect the society who actively involved in environment protection management from being sued or prosecuted.

29 Article 187 c KUHAP such as visum et repertum of a forensic expert. Second, expert testimony is as evidence which the expert is directly presented at trial, and his/her testimony is recognized under the official record of the court. ${ }^{30}$ This dualism is related to the minimum evidence to be fulfilled at the criminal trial and be considered by the judge in the verdict. ${ }^{31}$

Considering the characteristic or nature of scientific expert evidence, it is obvious that this type of evidence is not a material for a lawsuit. The process of rejected or objected from other party supposed to be at the evidentiary process. After that, judges will consider whether the evidence is relevant or excluded in their verdict since the judge is not bounded to use the expert's testimony to be considered.

If the Court considered the expert testimony, it means that judges are believed beyond a reasonable doubt regarding the correlation between presented scientific expert evidence and the case facts. So, scientific expert evidence is merely served the necessity of criminal law enforcement. It is a subject to be challenged related to the applied scientific methodology of the expert, and it is not a material for a civil lawsuit.

\section{CONCLUSION}

Evidentiary is a significant process under criminal justice procedure. In this process, presented evidence will be examined and will be used to prove the defendant's guilt. Many criminal cases require expert testimony to be presented in court,

30 M. Yahya Harahap, Pembahasan Permasalahan dan Penerapan KUHAP: Pemeriksaan Sidang Pengadilan, Banding, Kasasi, dan Peninjauan Kembali, Jakarta: Sinar Grafika, 2007, p303.

31 Article 183 and 184 KUHAP. 
particularly in explaining scientific evidence. Through his/her expertise, the expert will also tell about applied scientific theory, method, or technique in correlation with the facts of the case. This type of evidence is known as scientific expert evidence. For this matter, the U.S. Rules of Evidence set prong test regarding the admissibility of scientific expert evidence. In contrast, Indonesia does not set such rules yet. Lack of prong test in considering scientific expert evidence may hamper judge regarding the admissibility of such evidence at trial, moreover, if presented proof is contradictory one to another. In this matter, the role of the judge will be very significant, since he/she has an active role to explore presented scientific expert evidence. About consider scientific expert evidence under the verdict, the judge is not bounded to apply it. From these practices, it must be firmed that scientific expert evidence is material to be challenged under the evidentiary process, and it is not a civil lawsuit material.

\section{REFERENCES}

\section{Books}

Glover, Richard. 2015. Murphy on Evidence. Oxford University Press.

Harahap, M. Yahya. 2007. Pembahasan Permasalahan dan Penerapan KUHAP: Pemeriksaan Sidang Pengadilan, Banding, Kasasi, dan Peninjauan Kembali. Jakarta: Sinar Grafika.

\section{Journals}

Berger, Margaret A. 1994. "Procedural Paradigms for Applying the Daubert Test." 78 Minn. L. Rev. 1345.
Bucy, Pamela H. 1989. "White Collar Crime and the Role of Defense Counsel." 50 Ala. Law. 226.

Deaton, Dana G. 1996. "The Daubert Challenge to the Admissibility of Scientific Evidence." 60 Am. Jur. Trials 1.

Goodwin, Robert J. 2012. "An Overview of Alabama's New Daubert-Based Admissibility Standard." 73 Ala. Law. 196.

Gross, Samuel R. and Mnookin, Jennifer L. 2003. "Expert Information and Expert Evidence: A Preliminary Taxonomy." Seton Hall Law Review Vo. 34:141.

Primadianti, H., \& Zuhro, F. 2018. A Gap Between Right to Live Protection and Death Penalty in Indonesia (Judges Decision on Cases Threatened Death Penalty). In SHS Web of Conferences (Vol. 54, p. 02005). EDP Sciences.

Proveda, Tony G. 1994. "Rethinking White-Collar Crime." Wisconsin Lawyer. 45.

Rifai, E. 2017. "An Analysis of the Death Penalty in Indonesia Criminal Law." Sriwijaya Law Review. 1(1).

Schlegel, Kip, et al., 2000-2001. "Are White-Collar Crimes Overcriminalized? Some Evidence on the Use of Criminal Sanctions Against Securities Violators." 28 W. St. U. L. Rev. 117.

William Daubert, et al. Petitioners $v$. Merrel Dow Pharmaceuticals, INC., Respondent, On Writ of Certiorari to the United States Court of Appeals for the Ninth Circuit, 1993 WL 13006281 (U.S.) (Appellate Brief) United States Supreme Court Amicus Brief.

\section{World Wide Web}

Arumingtyas, Lusia. (2018). Kala Kuasa Hukum Nur Alam Perkarakan Saksi Ahli Lignkungan, Berikut Pandangan Koalisi. Available from: http://www.mongabay. co.id/2018/04/21/kala-kuasa-hukum-nur- 
alam-perkarakan-saksi-ahli-lingkunganberikut-pandangan-koalisi/. [retrieved: September 31, 2018].

Jemadu, Liberty. (2013). Forum Akademisi IT Pertanyakan Predikat "Ahli Telematika" Roy Suryo. Available from: http://www. beritasatu.com/kesra/134829-forumakademisi-it-pertanyakan-predikat-ahlitelematika-roy-suryo.html. [retrieved: September 31, 2018].

MaPPI FHUI. (2018). Diskusi Indonesian Center for Environment Law (ICEL) "Anti SLAPP dan Perlindungan Terhadap Kriminalisasi Aktivis, Available from: http://mappifhui. org/2018/02/13/diskusiindonesian-center-environment-law-icelanti-slapp-dan-perlindungan-terhadapkriminaliasi-aktivis/. [retrieved: October 30, 2018].

\section{Laws}

Constitutional Court Verdict Number 65/PUU-VIII/2010.

The Pekanbaru High Court verdict number 186/PID.SUS/2015/PT.PBR.

The 1981 Law No. 8 Concerning Criminal Law Procedure.

The 2009 Law No 32 Concerning the Environment Protection and Management.

Supreme Court Decree Number 36/KMA/5K/II/3013 about the Implementation of Guidelines for Handling Environment Cases.

The 2008 Circular Letter of the Supreme Court of the Republic of Indonesia No. 13 of 2008 on Requesting Expert Testimony. 